\title{
Circular local skin flap. A new approach to areola reconstruction ${ }^{1}$
}

\author{
Retalho circular de pele local. Uma nova abordagem para a reconstrução da aréola
}

\author{
Marcelo de Oliveira², Daniel Nunes ${ }^{3}$, Mirta Beolchi', André Vargas ${ }^{3}$ \\ 1. Research performed, Department of Plastic Surgery, Pontifical Catholic University of Rio de Janeiro (PUCRJ) and Carlos Chagas Institute of Post- \\ Graduate Medical Studies and Ivo Pitanguy Institute, Rio de Janeiro, Brazil. \\ 2. Assistant Professor, Plastic Surgery, PUCRJ and Carlos Chagas Post-Graduate Medical Institute, Rio de Janeiro, Brazil. \\ 3. Post-Graduate, Plastic Surgery, PUCRJ, Rio de Janeiro, Brazil. \\ 4. Plastic Surgeon, Specialist Member of the Brazilian Society of Plastic Surgery. Rio de Janeiro, Brazil.
}

\begin{abstract}
Purpose: Despite the numerous surgical options available today for nipple-areola reconstruction, the results are often unsatisfactory. The present study proposes a simple and efficient method for areola reconstruction that uses a circular local skin flap. Methods: We prospectively followed five patients that underwent areola reconstruction using a circular local skin flap. A circle, approximately $5 \mathrm{~cm}$ in diameter, was marked on the desired area for the new areola. A thin centripetal undermining of 1.5-2 cm was performed, which created a flap with a central pedicle of approximately 1-2 cm. After hemostasis, the thin flap was fixed in its former position with continuous sutures. Results:The mean procedure time was 20 minutes $( \pm 9)$. The postoperative results were classified as satisfactory by four of the five patients at six months postoperative. Due to superficial undermining, the resulting scar resembled the appearance of the transition from the mammary skin to the areola. Dermopigmentation was only required in one areola. No complications such as dehiscence, necrosis, hematoma, or infection occurred. Conclusion: This technique achieved satisfactory results with low morbidity and few complications, and is thus a potentially promising resource for areola reconstruction.
\end{abstract}

Key words: Mammaplasty. Nipples. Surgical Flaps.

\section{RESUMO}

Objetivo: A reconstrução da aréola tem sofrido muitas inovações. Apesar do grande número de opções cirúrgicas, os resultados são muitas vezes insatisfatórios. Este estudo descreve um procedimento simples e eficiente para a reconstrução da aréola com um retalho circular de pele local. Métodos: Os autores avaliaram prospectivamente cinco pacientes submetidas à reconstrução da aréola no período de 2004 a 2005. A reconstrução da aréola foi baseada em um retalho circular de pele local. A técnica inicia com a marcação de um círculo de aproximadamente cinco centímetros de diâmetro no local da nova aréola. Um descolamento centrípeto superficial de 1,5-2 cm é realizado, criando um retalho com pedículo central de aproximadamente 1-2 cm de diâmetro. Após a hemostasia, o fino retalho é suturado em sua antiga posição, com pontos contínuos. Resultados: O procedimento levou em média 20 minutos $( \pm 9)$. O resultado pós-operatório foi classificado como satisfatório por quatro das cinco pacientes no sexto mês de pós-operatório. Em virtude do descolamento superficial, o aspecto final da cicatriz simulou a transição entre a pele da mama e a aréola. Dermopigmentação foi necessária em apenas uma aréola. Não ocorreram complicações como deiscência, necrose, hematoma ou infecção. Conclusão: A técnica descrita apresentou resultados satisfatórios com morbidade reduzida e baixos índices de complicações; tornando-se, no arsenal do Cirurgião Plástico, uma alternativa interessante para a reconstrução da aréola. Descritores: Mamoplastia. Mamilos. Retalhos Cirúrgicos. 


\section{Introduction}

As the number of mammary reconstruction surgeries performed has increased in recent years, reconstructive surgery of the nipple-areola has also become more widespread ${ }^{1,2}$. Despite the numerous reconstructive techniques presently available, many women are dissatisfied with their final results ${ }^{3-6}$. Thus, the identification of an ideal reconstructive procedure remains important ${ }^{7-9}$. For successful nipple-areola reconstruction, plastic surgeons need a technically practical alternative that will provide natural results, with a low morbidity rate and cost ${ }^{2,10}$. The present study presents a simple and effective form of areola reconstruction that uses a circular local skin flap.

\section{Methods}

Five patients that underwent areola reconstruction between January 2004 and December 2005 were prospectively followed. Reconstruction was performed in a private practice setting, and a local skin flap technique was performed in all cases. This surgical technique uses a circular local skin flap with a central pedicle. The procedure was performed on an ambulatory basis with general sedation and local anesthesia. Using an areolotome, a circle was marked to identify the desired location for the new areola ${ }^{11}$ (Figure 1A). The circle diameter varied according to the size of the contralateral areola, with a mean measure of 5 $\mathrm{cm}$. The circle was incised down to the dermis (Figure 1B) and the skin was superficially and centripetally undermined approximately 1-2 cm. A thin skin flap with a central pedicle of approximately 2-3 cm was created (Figure 1C). After hemostasis, the flap was fixed in its former position with 5.0 Mononylon running sutures (Figure 1D). Figure 2 shows the transoperative sequence in detail. Unilateral nipple reconstruction was performed in a single surgery using a graft from the contralateral nipple. Bilateral nipple reconstructions required a second surgery for the local flaps or auricular cartilage graft. The dressing was compressive, except at the nipple area. The sutures were removed 14 days postoperative and sun exposure was recommended. Areola pigmentation was noticeable after three postoperative weeks. After surgery, the patients returned for a medical consult every week during the first postoperative month and then every two months until the sixth postoperative month. A final review was scheduled for one year postoperative. Patient complaints, complications, and degree of satisfaction were recorded and photographic documentation was performed.

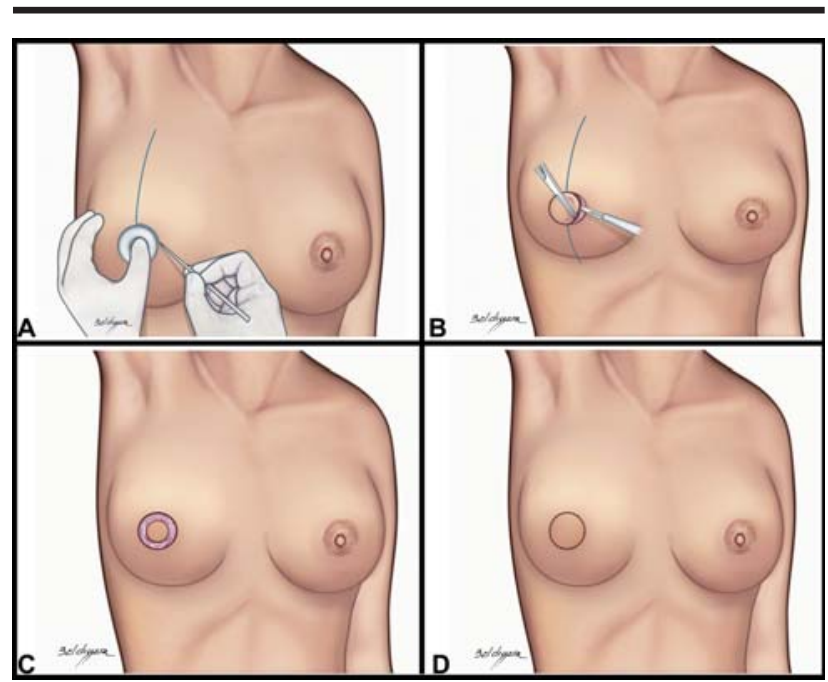

FIGURE 1 - A: Circular marks on the position of the new areola. B: undermining of the circular local skin flap (fine thickness). C: the circular skin flap and its central pedicle. D: The flap placed back on its former position

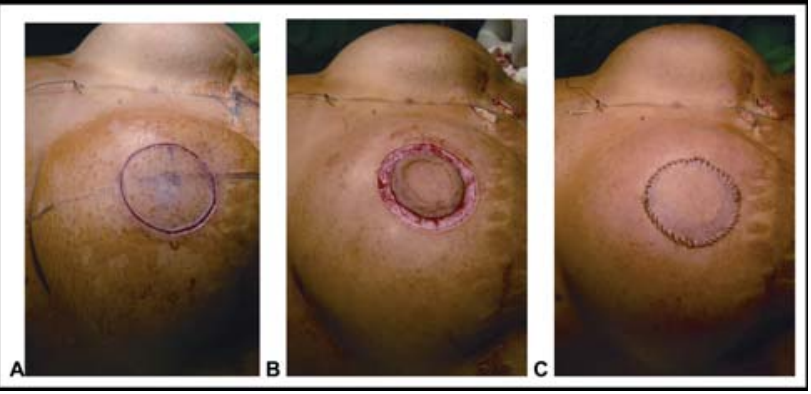

FIGURE 2 - Transoperative sequence. A: the circular local skin flap incised. B: the flap undermined and its central pedicle. C: the flap sutured on its former position

\section{Results}

Seven areolas were reconstructed in five patients using the local skin flap technique. Table 1 summarizes patient characteristics. The average surgical follow-up time was 8 months $( \pm 3)$. Two patients did not complete the follow-up and were excluded from the study. The average surgical time for each areola was 20 minutes $( \pm 9)$. No complications, such as hematoma, dehiscence, infection, or necrosis, were reported. At six months postoperative, four patients $(80 \%)$ were satisfied with their results. Patient $\mathrm{C}$ did not complete the follow-up at the $12^{\text {th }}$ month. Of the four remaining patients, three were very satisfied (75\%) and one was poorly satisfied, due to areola dispigmentation. This patient was given complementary dermopigmentation and was then satisfied with her final results. Table 2 summarizes patient satisfaction. The texture and color tone of the new areola was comparable to that of the contralateral areola. Figures 3-5 show patient clinical evaluations. 
TABLE 1 - Patient characteristics

\begin{tabular}{lccccl}
\hline & Age & Skin Collor & Pathology & Reconstruction & Technique \\
\hline Patient A & 26 & B & TF & Bilateral & E+I \\
Patient B & 55 & B & Ca & Unilateral & TRAM \\
Patient C & 52 & W & Ca & Bilateral & TRAM Div \\
Patient D & 54 & W & Ca & Unilateral & LD \\
Patient E & 49 & W & Ca & Unilateral & TRAM \\
\hline
\end{tabular}

Age: years; Skin Collor: White (W), Black (B); Pathology: Invasive Duct Carcinoma (Ca), Phyllodes Tumor (TF); Technique: Transverse Rectus Abdominis Flap (TRAM), Tissue Expansion associated with Submuscular Silicone Implant (E+I), Transverse Rectus Abdominis Flap Divided in Two (TRAM Div), Latissimus Dorsi Flap (LD)

TABLE 2 - Post-operative patient satisfaction

\begin{tabular}{cllc}
\hline & $3^{\text {th }}$ month & $6^{\text {th }}$ month & $12^{\text {th }}$ month \\
\hline Patient A & Satisfactory & Satisfactory & Satisfactory \\
& Satisfactory & Satisfactory & Satisfactory \\
Patient B & Satisfactory & Satisfactory & Satisfactory \\
Patient C & Satisfactory & Satisfactory & Satisfactory \\
& Satisfactory & Satisfactory & Satisfactory \\
Patient D & Satisfactory & Satisfactory & Satisfactory $*$ \\
Patient E & Satisfactory & Unsatisfactory & - \\
\hline
\end{tabular}

Observation: patients A and C were submitted to bilateral areola reconstruction.

* dermopigmentation was required.

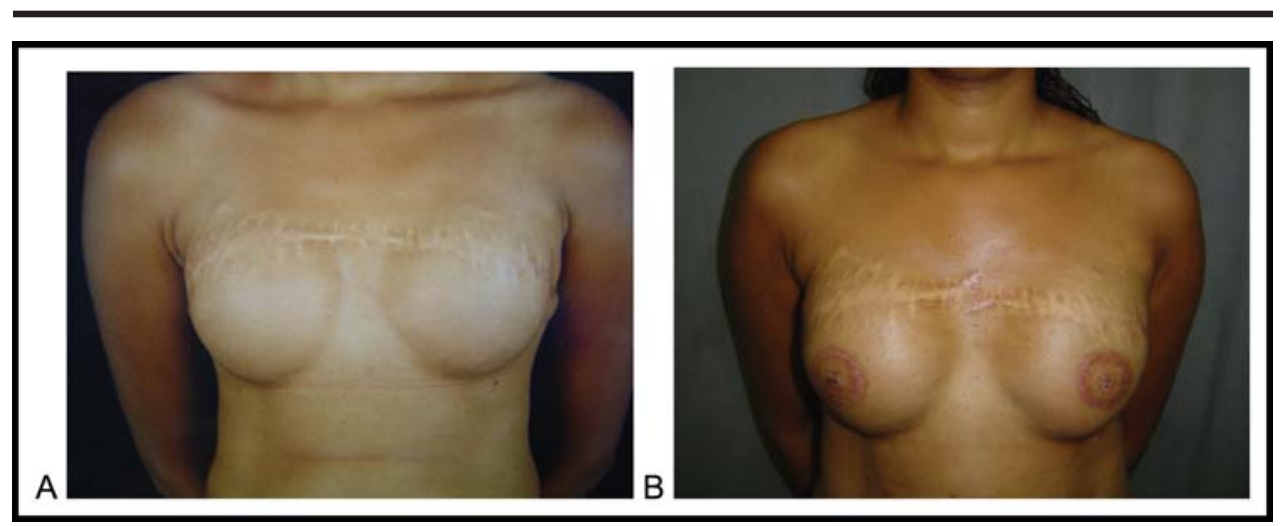

FIGURE 3 - Patient A. A. Preoperative areola reconstruction view: patient submitted to bilateral breast reconstruction with tissue expansion and submuscular silicone implants $(400 \mathrm{ml})$. B. Postoperative view: twelve months after areola reconstruction with the circular local skin flap and one month after nipple construction with auricular cartilage

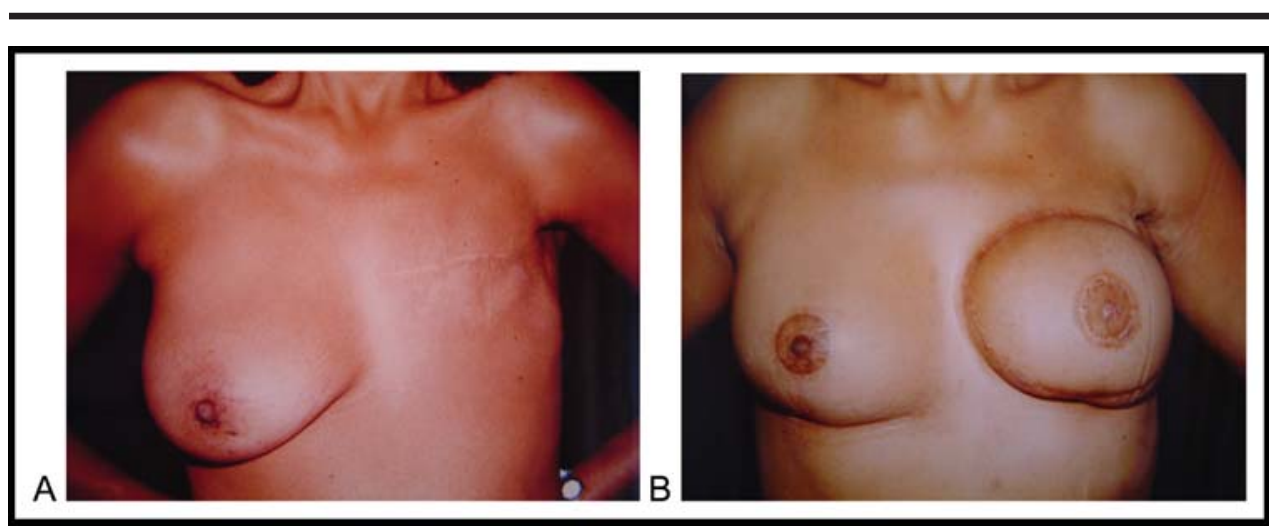

FIGURE 4 - Patient B. A. Preoperative view: patient candidate to left breast reconstruction. B. Postoperative view - twelve months after areola and nipple reconstruction 


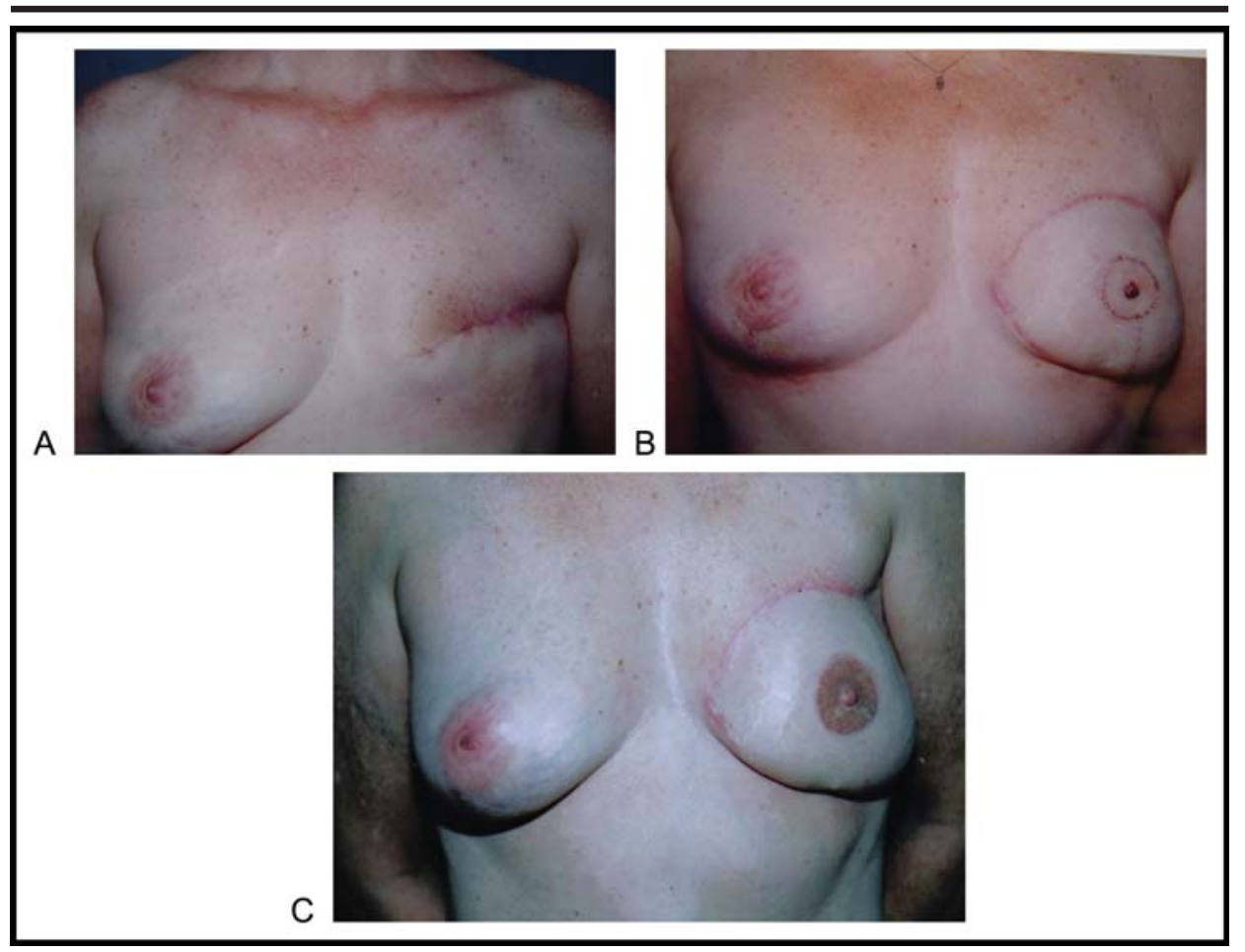

FIGURE 5 - Patient D. A. Preoperative view: patient candidate to left breast reconstruction. B. Postoperative view: six months after TRAM Flap for left breast reconstruction and areola reconstruction with the circular local skin flap. C. Postoperative view: six months after areola dermopigmentation

\section{Discussion}

Despite recent improvements in breast reconstruction, patients are often dissatisfied with their nipple-areola reconstruction ${ }^{1,7,8,11}$. However, there is no consensus regarding the best choice for areola reconstruction ${ }^{1,4}$. Existing reconstruction techniques are not ideal and the choice of the technique often varies according to the surgeon's experience ${ }^{4,5,9}$. A full thickness skin graft is the most commonly used technique ${ }^{1}$. Depending on the desired color tone for the new areola, the plastic surgeon may take skin from the inguinal region, the perineal region, the retroauricular region, the upper eyelid, or the contralateral areola 1,7,12,13. However, such grafting often does not result in a pigmentation comparable to a natural areola ${ }^{1,5,9}$. Moreover, complications such as graft integration failure, impaired scar quality, and local infections often occur with grafting ${ }^{13}$. In addition, the removal of skin from other surgical sites increases the aggressiveness of the procedure ${ }^{6,7,10,13}$. Many patients are also opposed to the scarring of a previously untouched area. Some surgeons have advocated the use of non-surgical procedures, such as dermopigmentation, for areola reconstruction ${ }^{8,10}$. However, this method has also been criticized and is not widely used due to the difficultly in acquiring materials and the need for specialized training ${ }^{8}$. Even those surgeons in favor of this technique point out that experience with pigmentation is essential for successful results ${ }^{10}$. The texture of the new areola often differs from that of the contralateral areola, and over time a gradual loss of pigmentation requires repeated procedures ${ }^{5}$. Alternatively, skin grafting with postoperative dermopigmentation may provide more natural results ${ }^{2,14}$. The use of a circular local skin flap, as described here, is an alternative for cases in which the contralateral areola does not have sufficient skin for donation, or in cases of bilateral reconstruction. In the present study, we found this technique to be superior to other existing alternatives. For example, we had a high rate of satisfaction among the patients, and the color of the new areola was comparable to that of the contralateral areola. The use of a thin skin flap leads to local hemosiderin sedimentation that darkens the flap and simulates the color of a natural areola ${ }^{15}$. Only one patient in the present study required postoperative dermopigmentation to improve their results. Furthermore, because the flap is slightly retracted during surgery, the texture of the new areola is also more natural.

\section{Conclusion}

The circular local skin flap technique is a simple, safe, and effective option for areola reconstruction. It can be achieved in a single surgery, which reduces cost, and the local approach has a lower complication rate. Therefore, we found the use of a circular flap to be an effective alternative for successful areola reconstruction. 


\section{References}

1. Maxwell GP. Breast reconstruction following mastectomy and surgical management of the patient with high-risk breast disease. In: Smith JW, Aston SJ. Grabb and Smith. Plastic surgery. Boston: Little Brown; 1991. p. 1203-47.

2. Bogue DP, Mungara AK, Thompson M, Cederna PS. Modified technique for nipple-areolar reconstruction: a case series. Plast Reconstr Surg. 2003;112(5):1274-8.

3. Guerra AB, Khoobehi K, Metzinger SE, Allen RJ. New technique for nipple areola reconstruction: arrow flap and rib cartilage graft for long-lasting nipple projection. Ann Plast Surg. 2003;50(1):31-7.

4. Jabor MA, Shayani P, Collins DR Jr, Karas T, Cohen BE. Nipple-areola reconstruction: satisfaction and clinical determinants. Plast Reconstr Surg. 2002;110(2):457-63.

5. Bhatty MA, Berry RB. Nipple-areola reconstruction by tattooing and nipple sharing. $\mathrm{Br} \mathrm{J}$ Plast Surg.1997;50(5):331-4.

6. Chang BW, Slezak S, Goldberg NH. Technical modifications for on-site nipple-areola reconstruction. Ann Plast Surg.1992;28(3):277-80.
7. Hartramp CR, Culbertson JH. A derma-fat flap for nipple reconstruction. Plast Reconst Surg.1984;73(6):982-6.

8. Spear SL, Convit R, Little JW. Intradermal tattoo as an adjunct to nipple-areola reconstruction. Plast Reconst Surg.1989;83(5):907-11.

9. Becker H, Prysi MF. A new technique for reconstructing montgomery's tubercles. Plast Reconstr Surg. 1990;86(1):147-8.

10. Eskenazi L. A one-stage nipple reconstruction with the "modified star" flap and immediate tattoo: a review of 100 cases. Plast Reconstr Surg.1993;92(4):671-7.

11. Oliveira M, Nunes D, Beolchi M, Vargas AF, Pitanguy I. Areola reconstruction with local tissue. Plast Reconstr Surg (in press).

12. Brent B, Bostwick J. Nipple-areola reconstruction with auricular tissues. Plast Reconstr Surg.1977;60(3):353-61.

13. Wexler MR, Onem RM. Areolar sharing to reconstruct the absent nipple. Plast Reconstr Surg.1973;51(2):176-8.

14. Gamboa-Bobadilla GM. Nipple reconstruction: the top hat technique. Ann Plast Surg. 2005;54(3):243-6.

15. Merlen JF, Coget J, Sarteel AM. Pigmentation and venous stasis. Phlebologie. 1983;36(4):307-14.

\section{Correspondence:}

Marcelo de Oliveira

Rua Afrânio de Melo Franco, 141/311

22430-060 Rio de Janeiro - RJ Brazil

Phone: (55 21)2259-9001 / 9988-0760

Fax: (55 21)2259-9001

dr.macelo.oliveira@hotmail.com
Conflict of interest: none

Financial source: none

Received: January 15, 2007

Review: March 14, 2007

Accepted: April 12, 2007

\section{How to cite this article}

Oliveira M, Nunes D, Beolchi M, Vargas A. Circular local skin flap. A new approach to areola reconstruction. Acta Cir Bras. [serial on the Internet] 2007 July-Aug;22(4). Available from URL: http://www.scielo.br/acb 